\section{Individual and social determinants of self-rated health and well-being in the elderly population of Portugal}

\author{
Determinantes individuais e sociais do estado \\ de saúde subjetivo e de bem-estar da \\ população sênior de Portugal
}

\section{Determinantes individuales y sociales del estado de salud subjetivo y bienestar de la población de la tercera edad de Portugal}

Pedro Alcântara da Silva 1,2

\section{Resumo}

This article aims to identify the main determinants of self-rated health and well-being in the elderly Portuguese population, using a set of dimensions including demographic and socioeconomic indicators, characteristics of interpersonal networks and social activities, health, sexual activity, representations of aging, and feeling of happiness. Taking socioeconomic, behavioral, and attitudinal predictors into account to analyze the explanatory value of the interrelated dimensions and weights for each factor, the author argues that social capital, activities associated with active aging, and greater optimism towards aging can contribute greatly to better self-rated health and wellbeing among the elderly, partially offsetting the effect of socioeconomic factors and illness associated with age.

Demographic Aging; Self-Assessment; Health of the Elderly
Neste artigo pretende-se identificar os principais determinantes da autoavaliação do estado de saúde e do bem-estar da população sênior, tendo em conta um conjunto de dimensões que reúnem indicadores demográficos e socioeconômicos, características das redes interpessoais e atividades sociais praticadas, de saúde, atividade sexual, de representações sobre o envelhecimento e sentimento de felicidade. A equação em simultâneo de preditores socioeconômicos e de caráter comportamental e atitudinal dessas várias vertentes, com o intuito de analisar o valor explicativo de cada uma das dimensões inter-relacionadas e o peso de cada um dos fatores, permite concluir que o social capital, a prática de atividades associadas ao envelhecimento ativo e um maior otimismo em relação ao envelhecimento podem contribuir em grande medida para uma melhor autoavaliação do estado de saúde e do bemestar dos mais velhos, compensando, em parte, o efeito de fatores socioeconômicos e de doença associados à idade.

Envelhecimento da População; Autoavaliação; Saúde do Idoso 


\section{Introduction}

Gradual decline in health status is the factor most frequently associated with age and perhaps the strongest conditioning factor in the aging process, particularly in the presence of chronic and multiple illness and physical and psychological impairments that affect the daily living and autonomy of the elderly.

Various factors can contribute to better health status and self-rated health, besides well-being and a feeling of greater happiness. Research has shown a clear relationship between use of time and participation in activities, degree of social integration, intensity and quality of social relations, and emotional and instrumental support received by the elderly (and also provided by them) and health, well-being, and quality of life in old age 1,2 .

In terms of their health, it is common for the elderly to require more support in the presence of illness, particularly when their functional capacities are temporarily or permanently affected and they experience difficulties in performing activities of daily living ${ }^{1}$. However, more recent research has attempted to extend beyond the support that personal and social networks can provide to the elderly in the case of illness. Studies on aging that focus on social relations and other related concepts in different contexts and societies have shown a clear relationship with health status and well-being throughout life, particularly in old age 3 .

Despite certain difficulties 4 , the research results have shown that persons who are more socially integrated, with more personal and social relations, and who are more satisfied with the quality of these relations display better health status than those with fewer social relations, thereby concluding that social networks and social support exert a clear influence on health ${ }^{1}$ and even reduce mortality risks 5 . More than effective and instrumental support in case of need, factors related to perceived support (i.e., the knowledge that this support can be obtained when needed) tend to produce a stronger and more consistent effect on the health and well-being of the elderly 6,7 .

The same is true for indicators pertaining to quality of life. Knowing that this is a multidimensional concept consisting of various conditions and ingredients over the course of life, most studies have shown that social relations emerge as a crucial condition for quality of life in the elderly, to the extent that humans are social beings with a basic need to relate to others as part of their wellbeing ${ }^{8}$. The overall impact of social networks and social support ends up affecting mortality. Structural or functional social support is largely a predictor of mortality, regardless of cause, age, gender, socioeconomic status, and initial health status 6,9.

Meanwhile, research in aging has also witnessed increased interest in how the elderly occupy their time and engage in socially productive activities, ranging from prolonging their participation in the workforce (paid work) to organized volunteer work and other forms of participation in public life 10,11,12. In fact, more recent years have seen a shift from conceptualizations of social integration with a focus on roles and activities reserved for the elderly (and the properties of the social fields to which they belong and in which they participate) to an approach more oriented towards an analysis of networks and discussion on social capital 11. From the analytical point of view, activity, network, and social capital have almost always been treated separately, which is not the most adequate approach when the aim is to analyze how the elderly remain socially connected throughout the later stages in life. Rather, the three approaches should be linked, to the extent that the category "activity" refers to opportunities and demands that make individuals socially active, while the category "network" centers on the social relations underlying such opportunities and demands, where social capital refers to the way individuals participate in society and the social connections and ties they develop, considering the social and cultural context to which they belong. In a broader sense, social capital is a measure of social integration and cohesion, with decisive implications for the health, quality of life, and well-being of the elderly 11,12,13.

In the current study, health is measured as self-rated health status and well-being through evaluation of the feeling of happiness. Self-rated individual health has proven to be a robust indicator of each person's overall health status, with a high predictive value for mortality, independently of medical, behavior, or psychosocial factors associated with health and disease 14 . Individual subjective well-being (or feeling of happiness, as synonymous) is associated with the common concept of what a satisfactory life means, based not only on the presence of a specific set of objective and interrelated circumstances and living conditions, but also on the way these are perceived and experienced. The satisfaction each person feels with life in general thus captures a reflexive assessment of the way such satisfaction unfolds in daily life. It allows evaluating which circumstances and conditions are important for subjective well-being and measuring and understanding the difference between the objective living conditions each person experiences and the way they assess such conditions 15,16. 
Research has attempted to unveil the relationship between self-rated health status and the diversity and intensity of social activities, social capital, or characteristics of the personal networks to which older people belong. The same is true for well-being, both measuring the influence of these types of variables on this generic indicator of perceived quality of life and also the impact of health status. Rather than approaching the individualized relationship of each of these social watersheds (as is usually done), the current article attempts to identify the main determinants of self-rated health status and well-being in the elderly population based on a set of simultaneously operationalized essential dimensions that combine demographic and socioeconomic indicators, characteristics of interpersonal networks and social activities, health characteristics, sexual activity, and happiness. The equation of socioeconomic, behavioral, and attitudinal predictors from these various watersheds also allows verifying the explanatory value of each interrelated dimension and each factor's weight for better health status and quality of life in the elderly from a global perspective, taking into account the design of the proposed analytical models.

\section{Methods}

\section{Sample}

The results presented here come from a sociological study on aging processes (uses of time, social networks, and living conditions) that was based on a survey with a structured questionnaire, applied in 2011 to a representative probabilistic sample of the population from continental Portugal over 50 years old $(\mathrm{N}=1,761,852)$ in three stages: (1) selection of sampling points based on identification of all the localities stratified by 5 regions (NUTS II) and by housing area (number of inhabitants in the localities), proportional to the population's distribution based on the General Population and Housing Census; (2) random selection of the starting points in each locality based on postal codes; and (3) selection of households (using the random route method) and interviewees (the person with the most recent birthday in the selected household). The data were collected by trained interviewers using the CAPI procedure (Computer Assisted Personal Interview). A final sample of 1,000 valid interviews was obtained with a maximum sampling error of $\pm 3 \%$ for a $95 \%$ confidence interval. Definition of the sample size considered as unknown the proportion of individuals in the population with negative or positive assessment of both de- pendent variables studied here, thus using 0.5 as the prevalence of positive self-rated health status and feeling of happiness.

\section{Variables and measures}

Due to their psychological meaning, the dependent variables were treated as continuous 17,18 . Using hierarchical multiple linear regression models by blocks, the study attempted to identify the predictors of self-rated health status and happiness, considering the above-mentioned set of dimensions, but adjusting the potential explanatory factors within each dimension in each model, taking into account the known theoretical background. Table 1 shows the descriptive statistics for the study variables.

The variables thus included a set of demographic and socioeconomic indicators such as age, gender, education, profession, employment status, income, and housing status.

The set of indicators pertaining to personal networks consisted of the size and composition of each interviewee's interpersonal network (family or non-family); characterization of the family unit, that is, whether the interviewee lived alone or with others; frequency with which the person felt the need for emotional support and whether he or she wished to have more help or support when they felt alone or sad; and manifestations of affect.

The social activities dimension included indicators on the number and frequency of activities at home and away from home. This dichotomy allows evaluating the social context in which such activities occur, where those performed away from home are assumed to involve more physical activity, predisposition, and social participation, while those performed at home are usually more physically passive activities, and especially practiced individually 19,20 . The number of activities is also crucial, to the extent that it reinforces the degree of participation in both domains 21 .

These indicators result from the combination of a wide range of activities, based on which an index was constructed for practices associated with active aging, drawing on a principal components factor analysis (three-factor forced extraction and Varimax rotation): the first factor aggregated 11 activities and points to the underlying dimension of practices associated with the concept of active aging (Kaiser-Meyer-Olkin = 0.790; factor loads ranging from 0.70 to 0.28 ; explained variance $=18.1 \%$; Cronbach's alpha $=0.69$ ): using a computer; attending cultural events; listening to music; listening to the radio; attending courses or training activities; practicing sports; 
Table 1

Summary of descriptive statistics on variables related to self-rated health status and well-being in elderly Portuguese, 2011.

\begin{tabular}{|c|c|c|c|c|c|c|}
\hline & $\mathrm{n}$ & $\%$ & Mean & Minimum & Maximum & SD \\
\hline \multicolumn{7}{|l|}{ Dependent variables } \\
\hline Self-rated health status & & & 3.13 & 1.00 & 5.00 & 0.908 \\
\hline Very bad & 53 & 5.3 & & & & \\
\hline Bad & 133 & 13.3 & & & & \\
\hline Fair & 504 & 50.5 & & & & \\
\hline Good & 246 & 24.6 & & & & \\
\hline Very good & 62 & 6.3 & & & & \\
\hline Total & 997 & 100.0 & & & & \\
\hline Feeling of happiness & & & 3.70 & 1.00 & 5.00 & 0.764 \\
\hline Very unhappy & 11 & 1.1 & & & & \\
\hline Unhappy & 58 & 5.8 & & & & \\
\hline Neither happy nor unhappy & 246 & 24.7 & & & & \\
\hline Happy & 587 & 59 & & & & \\
\hline Very happy & 93 & 9.3 & & & & \\
\hline Total & 995 & 100.0 & & & & \\
\hline \multicolumn{7}{|l|}{ Demographic and socioeconomic } \\
\hline Age & - & - & 65.26 & 50.00 & 97.00 & 10.261 \\
\hline Gender & & & - & - & - & - \\
\hline Male & 447 & 44.7 & & & & \\
\hline Female & 553 & 55.3 & & & & \\
\hline Total & 1,000 & 100.0 & & & & \\
\hline Education & & & - & - & - & - \\
\hline Can neither read nor write & 61 & 6.2 & & & & \\
\hline $\begin{array}{l}\text { Can read and write/1st cycle primary } \\
\text { school }\end{array}$ & 515 & 51.9 & & & & \\
\hline 2nd cycle primary school & 65 & 6.5 & & & & \\
\hline 3rd cycle primary school & 140 & 14.1 & & & & \\
\hline Secondary school & 104 & 10.4 & & & & \\
\hline University & 108 & 10.9 & & & & \\
\hline Total & 993 & 100.0 & & & & \\
\hline Profession * & & & - & - & - & - \\
\hline Owners, managers, professionals & 70 & 7.7 & & & & \\
\hline Middle and university level personnel & 148 & 16.2 & & & & \\
\hline Non-manual workers & 260 & 28.4 & & & & \\
\hline Skilled manual workers & 289 & 31.6 & & & & \\
\hline Unskilled manual workers & 147 & 16.0 & & & & \\
\hline Total & 914 & 100.0 & & & & \\
\hline Employment status & & & - & - & - & - \\
\hline Employed & 249 & 25.7 & & & & \\
\hline Retired & 573 & 59.2 & & & & \\
\hline Unemployed & 77 & 7.9 & & & & \\
\hline Housework & 69 & 7.2 & & & & \\
\hline Total & 968 & 100.0 & & & & \\
\hline
\end{tabular}

(continues) 
Table 1 (continued)

\begin{tabular}{|c|c|c|c|c|c|c|}
\hline & $\mathrm{n}$ & $\%$ & Mean & Minimum & Maximum & SD \\
\hline Income bracket ** & - & - & 4.31 & 1.00 & 7.00 & 1.623 \\
\hline 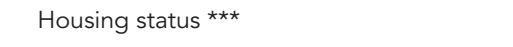 & & & 1.43 & 1.00 & 4.00 & 0.742 \\
\hline In good or perfect state of repair & 676 & 69.5 & & & & \\
\hline Needs minor repairs & 193 & 19.9 & & & & \\
\hline Needs some repair work & 80 & 19.9 & & & & \\
\hline Needs major repair work & 23 & 2.3 & & & & \\
\hline Total & 972 & 100.0 & & & & \\
\hline \multicolumn{7}{|l|}{ Personal networks } \\
\hline Size of network\# & - & - & 2.38 & 1.00 & 8.00 & 1.37 \\
\hline Composition of network & & & - & - & - & - \\
\hline Predominantly family & 687 & 76.0 & & & & \\
\hline Predominantly non-family & 217 & 24.0 & & & & \\
\hline Total & 904 & 100.0 & & & & \\
\hline Living situation & & & - & - & - & - \\
\hline Living alone & 201 & 20.1 & & & & \\
\hline Living with others & 799 & 79.9 & & & & \\
\hline Total & 1,000 & 100.0 & & & & \\
\hline Frequency of need for emotional support & & & 2.36 & 1.00 & 4.00 & 1.039 \\
\hline Never & 275 & 27.5 & & & & \\
\hline Rarely & 243 & 24.4 & & & & \\
\hline Sometimes & 331 & 33.2 & & & & \\
\hline Often & 149 & 14.9 & & & & \\
\hline Total & 998 & 100.0 & & & & \\
\hline Needs more emotional support & & & - & - & - & - \\
\hline Yes & 349 & 35.8 & & & & \\
\hline No & 625 & 64.2 & & & & \\
\hline Total & 974 & 10.0 & & & & \\
\hline Expression of affects \#\# & - & - & 2.99 & 1.00 & 6.00 & 1.518 \\
\hline \multicolumn{7}{|l|}{ Social activities } \\
\hline Number of activities at home \#\#\# & - & - & 5.83 & 0.00 & 10.00 & 2.104 \\
\hline Number of activities away from home & - & - & 2.91 & 0.00 & 10.00 & 1.759 \\
\hline Number of activities mostly at home & - & - & 4.69 & 0.00 & 6.00 & 1.821 \\
\hline $\begin{array}{l}\text { Number of activities mostly away from } \\
\text { home }\end{array}$ & - & - & 1.99 & 0.00 & 6.00 & 1.25 \\
\hline Belongs to some association $\S$ & & & 1.98 & 1.00 & 4.00 & 1.045 \\
\hline Never belonged & 427 & 43.0 & & & & \\
\hline Used to belong & 285 & 28.7 & & & & \\
\hline Belongs as non-active member & 157 & 15.8 & & & & \\
\hline Belongs as active member & 125 & 12.6 & & & & \\
\hline Total & 994 & 100.0 & & & & \\
\hline Active aging index & - & - & 2.51 & 1.00 & 4.73 & 0.83 \\
\hline Representations of aging $\S \S$ & - & - & 3.85 & 1.00 & 5.00 & 0.742 \\
\hline
\end{tabular}

(continues) 
Table 1 (continued)

\begin{tabular}{|c|c|c|c|c|c|c|}
\hline & $\mathrm{n}$ & $\%$ & Mean & Minimum & Maximum & SD \\
\hline \multicolumn{7}{|l|}{ Health } \\
\hline Chronic disease & & & - & - & - & - \\
\hline Yes & 538 & 53.9 & & & & \\
\hline No & 460 & 46.1 & & & & \\
\hline Total & 998 & 100.00 & & & & \\
\hline Physical and psychological impairments & & & 1.54 & 1.00 & 4.00 & 0.975 \\
\hline None & 740 & 74.7 & & & & \\
\hline Very few & 40 & 4.0 & & & & \\
\hline A few & 143 & 14.4 & & & & \\
\hline Many & 68 & 6.9 & & & & \\
\hline Total & 991 & 100.0 & & & & \\
\hline \multicolumn{7}{|l|}{ Sexual activity } \\
\hline Sexually active in the previous 3 months & & & - & - & - & - \\
\hline Yes & 462 & 53.3 & & & & \\
\hline No & 405 & 46.7 & & & & \\
\hline Total & 867 & 100.0 & & & & \\
\hline Importance of sexual activity & & & 2.52 & 1.00 & 4.00 & 1.071 \\
\hline Unimportant & 235 & 25.7 & & & & \\
\hline Slightly important & 139 & 15.2 & & & & \\
\hline Important & 365 & 40.0 & & & & \\
\hline Very important & 174 & 19.1 & & & & \\
\hline Total & 914 & 100.0 & & & & \\
\hline
\end{tabular}

SD: standard deviation.

Note: Dummy variables in the regression models included gender (reference group = female); profession (reference group = skilled manual workers; situation in the profession (reference group = skilled manual workers); composition of network (reference group = family network); living situation (reference group = living with others); more emotional support (reference group $=$ no); chronic disease (reference group = yes); sexually active in previous three months (reference group = yes). All the statistical analyses used IBM SPSS version 21 (IBM Corp., Armonk, USA).

* Profession consisted of the combination of each individual's profession (National Classification of Professions 2010 National Institute of Statistics, Portugal) and employment status;

** Family member's income bracket (monthly net mean in Euros), where " $1=A^{\prime \prime}$ is the lowest value $(\leq € 350)$ and "7 = G" is the highest ( $>€ 2,500$ );

$\star \star \star$ Classification of the housing's state of repair was based on the interviewer's assessment;

\# Number of persons listed by the interviewee when asked about the persons he or she had spoken to in the previous 12 months about day-to-day problems, concerns, or other topics he or she considered important (up to 8 important persons, including family and non- family);

\#\# The variable resulted from the construction of an index based on three questions concerning the frequency with which they had hugged, kissed, or caressed their spouse or partner, the frequency with which they had hugged an adult (other than spouse or partner), and the frequency with which they had hugged a child (in the previous four weeks and with answers varying from " 1 = Daily" to "6 = Never"), showing Cronbach's alpha $=0.56$;

\#\#\# The indicators for activities resulted from the type and frequency with which each of the following activities was performed, ranging from "1 = Never" to "6 = Daily": "household chores", "handicrafts, manual work, home repairs", "free-time computer use", "participation in events such as those held by political parties, trade unions, or civic movements", "visiting friends or acquaintances and inviting them to one's home", "crosswords or jigsaw puzzles", "flower or vegetable gardening", "reading", "listening to the radio", "watching TV", "keeping a pet", "listening to music", "outings", "practicing a sport", "performing some artistic activity", "going to the movies, concerts, theater, museums, galleries, or art exhibits", "attending sports events", "playing table games", "attending training courses or activities at one's own initiative";

(continues) 
$\S$ Resulted from the combination of two questions on whether the person is, used to be, or has never been a member of associations (sports clubs; trade unions, professional associations, company unions; political parties; and various associations such as those involving open-air and cultural activities, consumer groups, heritage group, parents' and educational communities, social solidarity, and neighborhood associations) and the frequency with which the person had participated in meetings, events, or reunions of these organizations in the previous twelve months (ranging from $1=$ "daily" to $6=$ "never"); $\S \S$ Resulted from the construction of an index based on a set of eight indicators ("feeling less and less respected"; "feeling more and more alone"; "knowing more what you want"; "continuing to make plans"; "taking less advantage of life"; "feeling like you wouldn't be missed"; and "still being capable of learning new things and having more free time", on a scale of agreement from 1 = "disagree totally" to 5 = "agree totally"). By recoding and orienting the scale of indicators in the same direction, and after finding a considerable degree of consistency between them (Cronbach's alpha $=0.71$ ), a single variable was constructed in which the lowest point on the scale (1) meant a "pessimistic view of aging" and the highest point (5) an "optimistic view").

reading; participating in political party events, trade unions, or civic movements; outings; visiting friends (or receiving visits from them); and performing artistic activities. These were mainly cultural, recreational, social, expressive, physical, and instrumental activities related to the principles recommended by the ideology of active aging, generally including health-promoting behaviors and social and personal factors that fit into the aging process and that allow greater cohesion and productivity 22 . Studies have shown the importance of physical activity, but also of the social, cultural, and civic participation, as well as of the involvement and inclusion in personal networks of different dimensions, to life satisfaction and personal well-being 19,23,24.

This set of predictors also included belonging to some association (sports, cultural) and representations of aging, which also relate to valuing a socially active life. Each individual's representations of the aging process (both their own and that of others) results not only from their experiences but also from overall attitudes shaped in society. This perception contributes to their wellbeing in their daily living and what they project into the future, generating more optimistic or pessimistic perspectives towards the meaning of aging.

As a predictor in the regression model for feeling of happiness, the health dimension included not only self-rated health status but also the presence or absence of chronic diseases and the existence of disease-related impairments.

Finally, the dimension of sexuality consisted of two indicators: the importance of sex in the interviewee's life and whether they reported sexual relations in the previous 3 months. Sexual activity has been viewed as an important factor for wellbeing and quality of life, although there are few studies on sexual behavior in the elderly. However, it is known that sexual activity changes with age and is associated with health status, to the extent that physiological alterations and illness can affect and even hinder sexual function in the elderly. Nevertheless, many elders maintain intimate relations with sexual desire and activity throughout life (although women tend to lose their partners earlier due to widowhood) 25 .

The regression model for self-rated health status added a dimension with happiness as the only predictor. For both regression models, an exploratory analysis was conducted to verify the minimum requirements for a parametric data analysis. According to the recommended procedures 26 , the assumptions for parametric analysis are ensured to the extent that the residuals analysis showed that they are homogeneous and normally distributed.

\section{Results}

\section{Predictors of self-rated health status}

In order to identify the main predictors of selfrated health status, an equation was created with a set of factors divided into six blocks intended to cover the fundamental dimensions of individuals' lives: the first block included demographic and socioeconomic factors; the second and third added indicators of personal networks and social activities; the fourth added health-related factors; the fifth included indicators related to sexual activity; and the sixth included a single variable for feeling of happiness. The analysis in blocks thus allowed verifying the weight of each potential explanatory factor in each set of variables in the equation, as new variables were added.

When only the demographic and socioeconomic variables were analyzed, the results showed the well-known explanatory factors associated with health inequalities found in other studies in Portugal, corroborating conclusions in 
the literature 27,28,29,30,31. The current study would tend to further aggravate these inequalities since it focused on an older population ( $>50$ years), including a significant proportion of lower-income elderly Portuguese who paid into the social security system at lower wage levels. This greater socioeconomic inequality would be expected to further increase health inequalities.

However, the following linear regression shows that the population's demographic and socioeconomic profile explained no more than $19.7 \%$ of the variance in self-rated health status; factors such as age and gender, and then education, profession, and income proved to be determinants: the oldest individuals and women, as well as those with less education and lower socioeconomic tended to report worse health status. When we included other variables related to the interviewees' personal networks (block 2), the number of personal relations also proved to be a preponderant predictor of self-rated health status, together with all the other indicators already mentioned. When indicators related to social activities were included in the equation (block 3), socioeconomic variables tended to lose their relevance and were no longer significant in this model, with only age and gender continuing to show explanatory power, along with frequency of activities performed away from home and individual and social activities associated with active aging: more frequent activities away from home and more activities associated with active aging were associated with better self-rated health status.

To control for the effect of illness on self-rated health status and partially for reverse causal inference (i.e., associations found between selfrated health status and social capital would exist especially because healthier individuals would tend to participate in social activities and have larger interpersonal networks, rather than the latter factors contributing per se to more positive health status, as we have intended to demonstrate), the model took into account a health dimension that was introduced after verifying the influence of demographic and socioeconomic factors, personal networks, and social activities.

As expected, when we added health factors in block 4 (defined in the strict sense of the word, such as the presence of at least one chronic disease and physical and psychological impairments), they became the most important explanatory factors for self-rated health status, nearly doubling the explained variance $(40.1 \%)$, although the other variables discussed in the previous block maintained their explanatory power (except for the distinction between men and women in self-rated health, which lost its impor- tance, while personal networks regained their explanatory relevance). Finally, analyzing the next two blocks (5 and 6), which included sexual activity and feeling of happiness, once again all these previously significant variables continued to be relevant and were joined by valuing sexuality and an optimistic view of life.

In short, larger network socials, more diversified and frequent individual and social activities (especially away from home), more highly valued and frequent sexual activity, and greater self-reported feeling of happiness were all associated with better self-rated health. Despite the partial loss of relevance of socioeconomic variables in this model, as demonstrated here they still played an important explanatory role in self-rated health. Contrary to some previous studies, in Portugal, living alone does not seem to predict self-rated health, or the composition of personal network (more family-based as opposed to more heterogeneous or non-family) $6,32,33$.

Naturally, chronic diseases and physical impairments played the most determinant role in self-rated health status, as expected. However, the fact that the other significant predictors maintained their relevance across the model (with or without inclusion of the disease variable) serves to reinforce the explanatory power of these factors for more positive self-rated health status (Table 2).

\section{Predictors of feeling of happiness}

The same statistical procedure performed for self-rated health status was then used to find the main predictors of feeling of happiness. The designation of the blocks used in this case was the same due to the nature of the respective indicators, although with some redefinitions as to the choice of the most adequate variables for finding factors to explain feeling of happiness.

In the first block, demographic and socioeconomic profile explained no more than $10.7 \%$ of the variance in feeling of happiness. Even so, women and the oldest tended to say they were less happy; however, income was the most important explanatory factor, i.e., less disposable income was associated with less happiness.

In fact, when new variables related to personal networks were included (block 2), income was the only factor that maintained the same level of significance, while gender and age became unimportant. Along with lower income, living alone, feeling the need for more emotion support in moments of sadness or loneliness, and lack of manifestation of affects were the most decisive factors for feeling less happy. 
Predictors of self-rated health (hierarchical multiple linear regression by blocks).

\begin{tabular}{|c|c|c|c|c|c|c|}
\hline & $\begin{array}{c}\text { Block } 1 \\
\text { (Demographic and } \\
\text { socioeconomic) }\end{array}$ & $\begin{array}{c}\text { Block } 2 \\
\text { (Personal } \\
\text { networks) }\end{array}$ & $\begin{array}{l}\text { Block } 3 \\
\text { (Social } \\
\text { activities) }\end{array}$ & $\begin{array}{l}\text { Block } 4 \\
\text { (Health) }\end{array}$ & $\begin{array}{l}\text { Block } 5 \\
\text { (Sexual } \\
\text { activity) }\end{array}$ & $\begin{array}{c}\text { Block } 6 \\
\text { (Happiness) }\end{array}$ \\
\hline Age & $-0.182 *$ & -0.198 * & $-0.160 * *$ & $-0.116 * \star$ & $-0.117 * \star \star$ & $-0.117 * \star \star$ \\
\hline Gender (female) & 0.155 * & 0.154 * & 0.117 ** & 0.033 & 0.019 & 0.023 \\
\hline Education & 0.140 ** & 0.137 ** & 0.042 & 0.024 & 0.032 & 0.045 \\
\hline $\begin{array}{l}\text { Owners, managers, and professionals (skilled } \\
\text { manual workers) }\end{array}$ & $0.100 * \star \star$ & $0.097 * * \star$ & 0.075 & 0.069 & 0.067 & 0.068 \\
\hline $\begin{array}{l}\text { Middle and university-level personnel (skilled } \\
\text { manual workers) }\end{array}$ & 0.063 & 0.057 & 0.044 & 0.026 & 0.013 & 0.013 \\
\hline Non-manual workers (skilled manual workers) & 0.022 & 0.022 & 0.016 & 0.019 & 0.013 & 0.021 \\
\hline $\begin{array}{l}\text { Unskilled manual workers (skilled manual } \\
\text { workers) }\end{array}$ & -0.021 & -0.016 & 0.000 & 0.005 & 0.001 & 0.002 \\
\hline Employed (retired) & 0.083 & 0.075 & 0.052 & -0.029 & -0.018 & -0.010 \\
\hline Unemployed (retired) & 0.009 & 0.011 & -0.015 & -0.029 & -0.030 & -0.029 \\
\hline Domestic (retired) & $0.099 * \star \star$ & $0.099 * \star \star$ & $0.081 * * \star$ & 0.027 & 0.033 & 0.039 \\
\hline Income & $0.093 * \star \star$ & $0.104 * \star \star$ & 0.052 & 0.005 & 0.007 & -0.008 \\
\hline Network size & & $0.076 * \star \star$ & 0.052 & $0.090 * *$ & 0.088 ** & 0.089 ** \\
\hline Network composition (family network) & & -0.049 & -0.050 & -0.038 & -0.033 & -0.019 \\
\hline Living situation (living with others) & & 0.040 & 0.029 & 0.010 & 0.014 & 0.037 \\
\hline Number of activities at home & & & 0.114 & 0.088 & 0.085 & 0.085 \\
\hline Number of activities away from home & & & 0.109 & 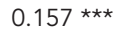 & 0.167 ** & $0.169 * \star$ \\
\hline Number of activities mostly at home & & & -0.067 & -0.054 & -0.062 & -0.052 \\
\hline Number of activities mostly away from home & & & 0.159 ** & 0.167 ** & 0.176 * & 0.176 * \\
\hline Belongs to some association & & & -0.031 & 0.025 & 0.028 & 0.036 \\
\hline Active aging index & & & $0.243 * \star$ & 0.196 ** & 0.187 ** & $0.143 * \star \star *$ \\
\hline Chronic disease (yes) & & & & 0.381 * & 0.372 * & 0.369 * \\
\hline Physical and psychological impairments & & & & -0.128 * & $-0.135 *$ & $-0.110 * *$ \\
\hline Sexual activity in previous 3 months (yes) & & & & & $0.085^{\star \star \star}$ & $0.110 * \star$ \\
\hline Importance of sexual activity & & & & & $0.110 * \star$ & $0.106 * \star$ \\
\hline Happiness & & & & & & 0.141 * \\
\hline$\Delta R^{2}$ & 0.211 & 0.009 & 0.042 & 0.161 & 0.008 & 0.015 \\
\hline Adjusted $R^{2}$ & 0.197 & 0.202 & 0.237 & 0.401 & 0.408 & 0.422 \\
\hline
\end{tabular}

Linear regression analysis, Enter method. Values are standardized regression coefficients (betas), marked when statistically significant: * $p<0.001$; ** $p<0.01$; *** $p<0.05$.

These factors maintained their relevance, although income lost some importance; meanwhile education and composition of one's personal network became significant when new indicators related to social activities were included (block 3). Thus, when combining these variables, fewer diversified individual and social activities (lower active aging index), less positive representations of aging, less education, and less familycentered relations were associated with less feeling of happiness.
The central importance of family relations for happiness among the elderly Portuguese appears to differ somewhat from international studies reporting that outside the family environment, elders with more friends, that have more regular contact with friends, and that derive some satisfaction from these relations express considerably fewer feelings of loneliness; there was a positive correlation between having friends and satisfaction with life and self-esteem 34 . Previous studies have shown that even among married elders with 
children, those with more (and closer) friends reported less loneliness than those who limited their relations to their own family 35 .

In fact, the importance of family relations and friendship is not identical when analyzing their contribution to elders' well-being: while most research has shown that contact with friends is determinant, studies in the relevance of the interactions whith family has shown that the effect on well-being is relatively small and that this relationship is less evident ${ }^{32}$. In this sense, as reported by Constança Paúl ${ }^{6}$ (p. 278), "We should distinguish between family networks and networks of friends. The former are 'involuntary' and based on a sense of obligation, while the latter involve a voluntary choice. This produces different effects on quality of life in the elderly, and support networks of friends and neighbors potentially have a more positive effect." Despite the extreme importance of family care and relations for the well-being of the elderly (among other reasons because family provides most of the supoort) 33 , one of the reasons identified for the fact that family relations are not always that positive is because "paternalism is frequent, inducing less well-being and satisfaction with life and even precipitating cognitive decline in the elderly" 36 (p. 283), since one of the basic pillars of active aging is "preservation of autonomy, at least psychologically (control) and socially (participation)" 36 (p. 284).

The fact that non-family relations were generally less predictive of happiness among Portuguese elders may be due to the greater relevance assigned to the family and the supremacy of family relations in Portugal as compared to other European countries 37 , which would tend to limit the relative benefits from more heterogeneous personal networks.

Finally, in addition to the above-mentioned factors, both self-rated health status (beyond more objective health conditions such as the presence of chronic diseases or physical and psychological impairments) and sexual activity also proved to be significant factors (blocks 4 and 5): as expected, worse self-rated health status and less sexual activity were associated with less happiness.

In short, observing the trend in the explained variance, increasing from $10.7 \%$ in the first block to $22.1 \%$ in the second block and from there to $31.4 \%$ in the third block (with minor variations from there on to the last two blocks), the current study concludes that personal networks and social activities were the most determinant dimensions for the elders' reported happiness. Not living alone, personal networks not confined to the family, less need for emotional support, more outward expressions of affection, more frequent and diversified individual and social activities, and more positive representations of aging were associated with greater feeling of happiness. Age, gender, schooling, and especially income and self-rated health status were also relatively important, although objective living conditions appeared to be somewhat underrated among the factors contributing to happiness (Table 3 ).

\section{Discussion}

A wide range of key personal and social factors affects the living situation of the elderly population and an understanding of aging processes. However, aging well and with quality of life naturally implies the existence of good health conditions, which cannot be dissociated from individuals' way of life, but which are decisive per se, and which may be the most important factors for active aging and well-being. But while health affects to a great extent what people can do, material conditions, activities, and the nature of personal and social networks also contribute greatly to better self-rated health status.

The results of the current multidimensional analysis are consistent with findings from other studies with more segmented approaches 38 , i.e., that the components of social capital 39 have protective effects on the health of the elderly, especially demonstrating the association between more positive self-rated health status and social participation, volunteering, and cultural activities $40,41,42$, along with the beneficial effects of personal networks and social support 43 . However, in this virtuous relationship one cannot overlook the weight of age-related morbidity and the well-known effects of health and disease-related socioeconomic inequalities on quality of life 44 , or the conditioning of individual options and experiences by life trajectories, which can either facilitate or hinder active aging.

Factors pertaining to personal networks and activities associated with active aging were the strongest determinants of happiness among the interviewees, partially exceeding objective living conditions and even age itself, even though income, schooling, and self-rated health status were also somewhat relevant. The results corroborate the main conclusions from studies on aging that identify health status 45 , absence of serious disease-related disabilities, and social ties in the context of professional, civic, recreational, cultural, and other activities away from home (or even within the family) as important predictors of active and successful aging with quality and greater satisfaction with life, protecting against the potential isolation from the transition to old age (65+) and 
Predictors of happiness (hierarchical multiple linear regression by blocks)

\begin{tabular}{|c|c|c|c|c|c|}
\hline & $\begin{array}{c}\text { Block } 1 \\
\text { (Demographic and } \\
\text { socioeconomic) }\end{array}$ & $\begin{array}{c}\text { Block } 2 \\
\text { (Personal } \\
\text { networks) }\end{array}$ & $\begin{array}{l}\text { Block } 3 \\
\text { (Social } \\
\text { activities) }\end{array}$ & $\begin{array}{l}\text { Block } 4 \\
\text { (Health) }\end{array}$ & $\begin{array}{l}\text { Block } 5 \\
\text { (Sexual } \\
\text { activity) }\end{array}$ \\
\hline Age & $-0.107 *$ & -0.040 & 0.025 & 0.037 & 0.080 \\
\hline Gender (female) & 0.102 ** & 0.073 & 0.053 & 0.039 & -0.002 \\
\hline Education & -0.014 & -0.002 & -0.104 * & -0.108 * & -0.109 * \\
\hline $\begin{array}{l}\text { Owners, managers, and } \\
\text { professionals (skilled manual } \\
\text { workers) }\end{array}$ & 0.023 & 0.017 & -0.002 & -0.013 & -0.014 \\
\hline $\begin{array}{l}\text { Middle and university-level } \\
\text { personnel (skilled manual workers) }\end{array}$ & 0.006 & 0.012 & 0.008 & 0.003 & 0.011 \\
\hline $\begin{array}{l}\text { Non-manual workers (skilled manual } \\
\text { workers) }\end{array}$ & -0.065 & -0.055 & -0.075 & -0.076 & -0.078 \\
\hline $\begin{array}{l}\text { Unskilled manual workers (skilled } \\
\text { manual workers) }\end{array}$ & -0.023 & 0.011 & 0.025 & 0.019 & 0.024 \\
\hline Employed (retired) & 0.024 & 0.012 & 0.023 & 0.015 & 0.008 \\
\hline Unemployed (retired) & 0.067 & 0.065 & 0.032 & 0.029 & 0.028 \\
\hline Domestic (retired) & 0.018 & 0.007 & -0.012 & -0.024 & -0.032 \\
\hline Member's income & $0.237 * \star \star$ & $0.164 * \star \star$ & 0.092 * & 0.081 & 0.068 \\
\hline Housing status & -0.068 & -0.026 & -0.007 & -0.009 & 0.002 \\
\hline Network size & & -0.034 & -0.050 & -.055 & -0.054 \\
\hline Network composition (family) & & -0.068 & $-0.079 *$ & $-0.075 *$ & -0.074 * \\
\hline Living situation (living with others) & & $-0.158 * \star \star$ & $-0.147 \star \star \star$ & $-0.148 * \star \star$ & $-0.143 * \star \star *$ \\
\hline $\begin{array}{l}\text { Frequency of need for emotional } \\
\text { support }\end{array}$ & & $-0.220 * \star \star$ & $-0.182 * \star \star$ & $-0.156 * \star \star$ & $-0.154^{\star \star \star}$ \\
\hline More emotional support (no) & & -0.058 & -0.015 & -0.007 & -0.005 \\
\hline Outward expression of affects & & $-0.169 * \star \star$ & $-0.095 *$ & -0.097 & $-0.092 *$ \\
\hline Belongs to some association & & & -0.060 & -0.060 & -0.064 \\
\hline Active aging index & & & $0.158 * \star \star$ & $0.142 \star \star$ & 0.118 * \\
\hline Representations of aging & & & $0.317^{\star \star \star \star}$ & $0.286 * \star \star$ & $0.275 \star \star \star *$ \\
\hline Self-rated health status & & & & 0.106 * & $0.117 * \star$ \\
\hline Chronic disease (yes) & & & & -0.033 & -0.038 \\
\hline $\begin{array}{l}\text { Physical and psychological } \\
\text { impairments }\end{array}$ & & & & -0.073 & -0.055 \\
\hline $\begin{array}{l}\text { Sexual activity in previous } 3 \text { months } \\
\text { (yes) }\end{array}$ & & & & & $-0.157 * \star \star$ \\
\hline Importance of sexual activity & & & & & 0.006 \\
\hline$\Delta R^{2}$ & 0.126 & 0.119 & 0.930 & 0.120 & 0.160 \\
\hline Adjusted $R^{2}$ & 0.107 & 0.221 & 0.314 & 0.322 & 0.336 \\
\hline
\end{tabular}

Linear regression analysis, Enter method. Values are standardized regression coefficients (betas), marked when statistically significant: * $p<0.001 ;$ ** $p<0.01$; *** $p<0.05$.

oldest old age (80+) 11,38. The results also corroborate the importance of personal networks and the crucial role of social ties and social support (actual or perceived) for overall quality of life among the elderly $38,46,47,48,49$ and mostly in situations of less autonomy 6 .
In general, the characteristics of the elders' personal networks and the way they occupy their free time are essential for both self-rated health status and feeling of happiness. While each person's self-rated health is obviously heavily conditioned by age-related disease, feeling 
of happiness tends to depend less on structural factors and objective living conditions, while personal networks and activities associated with active aging assume a crucial role, potentially helping offset or attenuate the effect of age. In other words, one tends to experience more illness as one grows older, but one is not necessarily unhappier if one enjoys quality of life, diversified individual and social activities to fill daily life, as well as a stable network of relationships which jointly help project a more optimistic view of aging.

The lack of studies focused specifically on the two dependent variables analyzed here in the Portuguese population and specifically in the elderly population constitutes a limitation to discussion of the current study's findings. This is especially true for self-rated health status, which lacks greater clarification concerning the weight of physical and mental health factors on self-rated health status, potentially contributing to the interpretative capacity of the explanatory impacts of the various dimensions analyzed here. Another limitation relates to controlling the effect of reverse causation, which still requires more in-depth investigation. The application of a structural equations model with adequate indicators could add information on the order and direction of causal relations between socioeconomic factors, social capital, and active aging that operate simultaneously on self-rated health status and well-being 50 .

\section{Resumen}

En este artículo pretendemos identificar los principales determinantes de la autoevaluación del estado de salud y bienestar de la población portuguesa de la tercera edad, teniendo en cuenta un conjunto de dimensiones que reúnen indicadores demográficos y socioeconómicos, características de las redes interpersonales y de las actividades sociales, salud, actividad sexual, representaciones del envejecimiento y sentimiento de felicidad. La ecuación simultánea de predictores socioeconómicos y de carácter comportamental, así como la actitud ante esos distintos factores, con el objetivo de analizar el valor explicativo de cada una de las dimensiones interrelacionadas y el peso de las mismas, permite concluir que el capital social, la práctica de actividades asociadas al envejecimiento activo y un optimismo más grande respecto al envejecimiento pueden contribuir en gran medida para una mejor autoevaluación del estado de salud y bienestar de personas mayores, compensando de ese modo, parcialmente, el efecto de los factores socioeconómicos y de las enfermedades asociadas a la edad.

Envejecimiento de la Población; Autoevaluación; Salud del Anciano

\section{Acknowledgments}

The original survey that produced the data presented in this article was conducted in the context of the research project Aging Processes in Portugal: Uses of Time, Social Networks, and Living Conditions, funded by the Francisco Manuel dos Santos Foundation. The overall study was coordinated by Manuel Villaverde Cabral, and the research team consisted of Pedro Moura Ferreira, Pedro Alcântara da Silva, Paula Jerónimo, and Tatiana Marques. The author wishes to thank the research project colleagues and Cícero Pereira, as well as the reviewers, for their useful comments and suggestions. 


\section{References}

1. Fernández-Ballesteros R. Social support and quality of life among older people in Spain. J Soc Issues 2002; 58:645-59.

2. Litwin H. Activity, social networks and well-being: an empirical examination. Can J Aging 2000; 19:343-62.

3. Sirven N, Debrand T. Social participation and healthy ageing: an international comparison using SHARE data. Soc Sci Med 2008; 67:2017-26.

4. Schreurs KMG, Ridder DTD. Integration of coping and social support perspectives: implications for the study of adaptation to chronic diseases. Clin Psychol Rev 2000; 17:89-112.

5. Musick MA, House JS, Williams DR. Attendance at religious services and mortality in a national sample. J Health Soc Behav 2004; 45:198-213.

6. Paúl C. Envelhecimento activo e redes de suporte social. Sociologia 2005; 15:275-87.

7. Norris F, Kaniasty K. Received and perceived social support in times of stress: a test of the social support deterioration deterrence model. J Pers Soc Psychol 1996; 71:498-511.

8. Fernández-Ballesteros R. Quality of life: concept and assessment. In: Adair JG, Belanger D, Dion KL, editors. Advances in psychological science. Hove: Psychology Press; 1998. p. 387-406.

9. Uchino B. Social support \& physical health. Understanding the health consequences of relationships. New Haven: Yale University Press; 2004.

10. Cornwell B, Laumann EO, Schumm L-P. The social connectedness of older adults: a national profile. Am Sociol Rev 2008; 73:185-203.

11. Kohli M, Hank K, Künemund H. The social connectedness of older Europeans: patterns, dynamics and contexts. J Eur Soc Policy 2009; 19:327-40.

12. Pichler F, Wallace C. Patterns of formal and informal social capital in Europe. Eur Sociol Rev 2007; 23:423-35.

13. Gray A. The social capital of older people. Ageing Soc 2009; 29:5-31.

14. Idler EL, Benyamini Y. Self-rated health and mortality: a review of twenty-seven community studies. J Health Soc Behav 1997; 38:21-37.

15. Kahneman D, Krueger AB. Developments in the measurement of subjective well-being. J Econ Perspect 2006; 20:3-24.

16. Dolan P, Peasgood T, White M. Do we really know what makes us happy? A review of the economic literature on the factors associated with subjective well-being. J Econ Psychol 2008; 29:94-122.

17. Michell J. Measurement scales and statistics: a clash of paradigms. Psychol Bull 1986; 100:398-407.

18. Velleman PF, Wilkinson L. Nominal, ordinal, interval, and ratio typologies are misleading. Am Stat 1993; 47:65-72.

19. Agahi N, Parker MG. Are today's older people more active than their predecessors? Participation in leisure-time activities in Sweden in 1992 and 2002. Ageing Soc 2005; 25:925-41.
20. Silverstein M, Parker MG. Leisure activities and quality of life among the oldest old in Sweden. Res Aging 2002; 42:528-47.

21. Baker LA, Cahalin LP, Gerst K, Burr J. Productive activities and subjective well-being among older adults: the influence of number of activities and time commitment. Soc Indic Res 2005; 75:431-58.

22. World Health Organization. Active ageing. A policy framework. Geneva: World Health Organization; 2002.

23. Agahi N, Silversein M, Parker MG. Late-life and earlier participation in leisure activities: their importance for survival among older persons. Act Adapt Aging 2011; 35:210-22.

24. Paillard-Borg S, Wang H-X, Winbland B, Fratiglioni L. Pattern of participation in leisure activities among older people in relation to their health conditions and contextual factors: a survey in Swedish urban area. Ageing Soc 2009; 29:803-21.

25. Laumann EO, Nicolosi A, Glasser DB. Sexual problems among women and men aged $40-80 \mathrm{y}$ : prevalence and correlates identified in the Global Study of Sexual Attitudes and Behaviors. Int J Impot Res 2005; 17:39-57.

26. Judd CM, McClelland GH. Data analysis: a model-comparison approach. Belmont: Wadsworth/ Thomson Learning; 2001.

27. Cabral MV, Silva PA. O estado da saúde em Portugal. Lisboa: Imprensa de Ciência Sociais; 2009.

28. Cabral MV, Silva PA, Mendes H. Saúde e doença em Portugal - inquérito aos comportamentos e atitudes da população portuguesa perante o sistema nacional de saúde. Lisboa: Imprensa de Ciências Sociais; 2002.

29. Marmot M. Introduction. In: Marmot M, Wilkinson R, editors. Social determinants of health. $2^{\text {nd }}$ Ed. Oxford: Oxford University Press; 2007. p. 1-5.

30. Pavão ALB, Werneck GL, Campos MR. Autoavaliação do estado de saúde e a associação com fatores sociodemográficos, hábitos de vida e morbidade na população: um inquérito nacional. Cad Saúde Pública 2013; 29:723-34.

31. Moraes JR, Moreira JPL, Luiz RR. Associação entre o estado de saúde autorreferido de adultos e a área de localização do domicílio: uma análise de regressão logística ordinal usando a PNAD 2008. Ciênc Saúde Coletiva 2011; 16:3769-80.

32. Hatch LR, Bulcroft K. Contact with friends in later life: disentangling the effects of gender and marital status. J Marriage Fam 1992; 54:222-32.

33. Paúl C. O papel das famílias na prestação de cuidados a crianças e idosos. In: Almeida L, Ribeiro I, editores. Família e desenvolviento. Portalegre: Associação dos Psicólogos Portugueses; 1994. p. 45-57.

34. Mullins LC, Smith R, Colquitt R, Mushel M. An examination of the effects of self-rated and objective indicators of health condition and economic condition on the loneliness of older people. J Appl Gerontol 1996; 15:23-37. 
35. Hall-Elston C, Mullins LC. Social relationships, emotional closeness, and loneliness among older meal program participants. Soc Behav Pers 1999; 27:503-17.

36. Paúl C. Lá para o fim da vida. Idosos, família e meio ambiente. Coimbra: Almedina; 1997.

37. Torres A, Mendes R, Lapa T. Families in Europe. Portuguese Journal of Social Science 2008; 7:49-84.

38. Fernández-Ballesteros R, Garcia LF, Abarca D, Blanc E, Efklides A, Moraitou D, et al. The concept of 'ageing well' in ten Latin American and European countries. Ageing Soc 2010; 30:41-56.

39. Putnam RD. Bowling alone: America's declining social capital. Journal of Democracy 1995; 6:65-78.

40. Kawachi I, Kennedy BP, Glass R. Social capital and self-rated health: a contextual analysis. Am J Public Health 1999; 89:1187-93.

41. Morrow-Howell N, Hinterlong J, Rozario PA, Tang F. Effects of volunteering on the well-being of older adults. J Gerontol B Psychol Sci Soc Sci 2003; 58:S137-45.

42. Veenstra G. Social capital, SES and health: an individuallevel analysis. Soc Sci Med 2000; 50:619-29.

43. Poortinga W. Social relations or social capital? Individual and community health effects of bonding social capital. Soc Sci Med 2006; 63:255-70.
44. Lima MG, Barros MBA, César CLG, Goldbaum M, Carandina L, Ciconelli RM. Impact of chronic disease on quality of life among the elderly in the state of São Paulo, Brazil: a population-based study. Rev Panam Salud Pública 2009; 25:314-21.

45. Lima MG, Barros MBA, Alves MCGP. Sentimento de felicidade em idosos: uma abordagem epidemiológica, ISA-Camp 2008. Cad Saúde Pública 2012; 28:2280-92.

46. Bowling A. Aspiration for older age in the 21st century: what is successful ageing? Int J Aging Hum Dev 2007; 64:263-97.

47. Phelan EA, Anderson LA, Lacroix A-Z, Larson EB. Older adults' views of 'successful ageing': how do they compare with researchers' definitions? J Am Geriatr Soc 2004; 52:211-6.

48. Knight T, Ricciardelli LA. Successful ageing: perceptions of adults aged between 70 and 101 years. Int J Aging Hum Dev 2003; 56:223-46.

49. von Faber M, van der Wield $A B$, van Excel E, Gussekloo J, Lagaay AM, van Dongen EV, et al. Successful ageing in the oldest old. Arch Intern Med 2001; 161:2694-700.

50. Der G. Commentary: structural equation modelling in epidemiology: some problems and prospects. Int J Epidemiol 2002; 31:1199-200.

Submitted on $04 /$ Oct $/ 2013$

Final version resubmitted on 21/Mar/2014

Approved on 25/Apr/2014 